\title{
Sludge reduction with Tubificidae and the impact on the performance of the wastewater treatment process
}

\author{
GUO Xue-song, LIU Jun-xin*, WEI Yuan-song, LI Lin \\ Research Center for Eco-Environmental Sciences, Chinese Academy of Sciences, Beijing 100085, China. E-mail: gxs0122@126.com
}

Received 17 March 2006; revised 8 May 2006; accepted 15 May 2006

\begin{abstract}
To reduce excess sludge, a Tubificidae reactor was combined with an integrated oxidation ditch with vertical circle (IODVC), and a new integrated system was developed for wastewater treatment. A pilot-scale of this integrated system was tested to investigate the sludge reduction with Tubificidae and the impact on effluent quality and sludge production. The dominant worm was Branchnria Sowerbyi in the Tubificidae reactor after inoculation of Branchnria Sowerbyi and Limnodrilns sp., and the maximal volume density of wet Tubificidae in vessels of the Tubificidae reactor was $17600 \mathrm{~g} / \mathrm{m}^{3}$. Two operational modes, treating the excess sludge (first mode) and the returned sludge (second mode) of IODVC by the Tubificidae reactor, were used in this experiment. The results showed that the excess sludge reduction rate was $46.4 \%$ in the first mode, and the average sludge yield of the integrated system was $6.19 \times 10^{-5} \mathrm{~kg}$ $\mathrm{SS} / \mathrm{kg}$ COD in the second mode. Though the sludge returned to IODVC via the Tubificidae reactor, it had little impact on the effluent quality and the sludge characteristics of the IODVC. No new type of recalcitrant substance in the supernatant was discharged into the environment when the sludge was treated by Tubificidae. The experimental results also indicated that no significant changes occurred on the viscosity, specific resistance, and the floc size distribution of the sludge.
\end{abstract}

Key words: integrated wastewater treatment system; sludge reduction; wastewater treatment; Tubificidae

\section{Introduction}

One of the most widely used methods for wastewater treatment is the activated sludge process. However, a large amount of excess sludge is produced from the process; if it is not properly disposed, the excess sludge may pose a potential threat to both environment and human health. Hence, it is necessary to research and develop suitable processes that can meet the requirements for both wastewater treatment and sludge treatment.

Recently, many studies have focused on sludge reduction induced by grazing on bacteria (Ratsak et al., 1993; Ratsak, 1994, 2001; Lee and Welander, 1994, 1996a, b; Ghyoot and Verstraete, 2000; Rensink et al., 1996; Rensink and Rulkens, 1997; Janssen et al., 1998; Zhang, 2000; Lapinski and Tunnacliffe, 2003; Wei et al., 2003a, b). Worms are the largest organisms observed during the microscopic investigation of activated sludge (Eikelboom, 2000). The performance of oligochaetes for sludge reduction in biological wastewater treatment has been paid more attention than that of protozoa for sludge reduction (Ratsak et al., 1993; Ratsak, 1994, 2001; Welander and Lee, 1994; Rensink et al., 1996; Rensink and Rulkens, 1997; Janssen et al., 1998; Zhang, 2000; Wei et al., 2003a, b). Different worms were found in their observations such as Nais elinguis, Pristina sp., and Aeolosoma hemprichicii,

Project supported by the National Natural Science Foundation of China (No. 50238050).*Corresponding author. E-mail: jxliu@ @rcees.ac.cn. but either Nais or Aeolosoma were predominant (Ratsak, 1994, 2001; Zhang, 2000; Wei et al., 2003a). On the basis of worms occurring in aerobic wastewater treatment processes, a novel worm-reactor was developed to enhance worm growth, and can be used to treat discharged excess sludge from the activated sludge process (Wei and Liu, 2005), or be integrated into the activated sludge process by treating the returned sludge (Wei et al., 2004). Although the worms grew very well in the worm-reactor and achieved a good sludge reduction rate in the bench-scale (Wei et al., 2003a, 2004; Wei and Liu, 2005), it is required to further study the impact of the sludge treated by worms on the aerobic wastewater treatment process, including effluent quality and sludge characteristics, i.e. whether some new recalcitrant substances will be discharged into the environment with effluent, and whether the activated sludge process will run for a long time without excess sludge waste. In addition, the practical application of sludge reduction induced by worms also needs more work on pilot-scale experiments.

Thus, the purpose of this study is to research and develop a suitable and clean process for both wastewater treatment and sludge treatment. A pilot-scale integrated system for wastewater treatment was tested in a municipal wastewater treatment plant of Beijing. This integrated system consists of an integrated oxidation ditch with vertical circle (IODVC) (Xia and Liu, 2004) and a Tubificidae reactor. In this study, the characteristics of sludge treated by Tubificidae 
and its impact on the effluent quality in the integrated system were investigated.

\section{Materials and methods}

\subsection{Pilot-scale integrated system}

As shown in Fig.1 of the experimental system, the working volumes of the IODVC and the Tubificidae reactor are $4.62 \mathrm{~m}^{3}$ and $0.091 \mathrm{~m}^{3}$, respectively. Thirty-three vessels, enhancing the resident area for Tubificidae, were loaded in the Tubificidae reactor because the Tubificidae are sessile worms. The length, width, and height of each vessel were $0.28 \mathrm{~m}, 0.03 \mathrm{~m}$, and $0.03 \mathrm{~m}$, respectively. The vessels were arrayed in the Tubificidae reactor, and the space between each vessel was $0.06 \mathrm{~m}$ and $0.08 \mathrm{~m}$ in the plane direction and the upright direction, respectively. Therefore, the total working volume of the vessel area was $0.038 \mathrm{~m}^{3}$. The sludge in the Tubificidae reactor was mixed and aerated using an air blower.

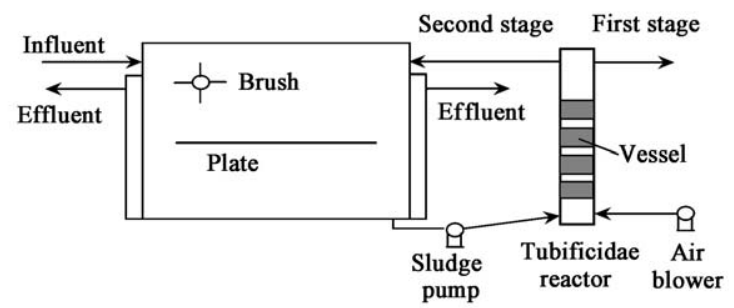

Fig. 1 A scheme of the integrated system for wastewater treatment.

\subsection{Operation conditions}

The integrated system was tested by a two running stage. The Tubificidae reactor treated the excess sludge of the IODVC in the first stage (from the beginning to the day 101 ), and then treated the returned sludge in the second stage (from the day 102 to the day 235). During 235 $\mathrm{d}$, the Tubificidae reactor was continuously fed with the sludge from the channel of the IODVC using a peristaltic pump. The flow of sludge from the IODVC was $0.140 \mathrm{~m}^{3} / \mathrm{d}$ and then the SRT in the IODVC was $30 \mathrm{~d}$. About $500 \mathrm{~g}$ wet weight of Tubificidae, including Branchnria Sowerbyi and Limnodrilns sp., was inoculated in the vessels of the Tubificidae reactor in the start-up stage. Therefore, the volume density of the wet weight of Tubificidae in the vessel region was $13158 \mathrm{~g} / \mathrm{m}^{3}$ in the inoculation. The wet weight of Tubificidae during the operation of the integrated system was only measured in vessels since almost all the Tubificidae resided in the vessels and some Tubificidae remaining on the bottom could not be sampled when the reactor was working. The hydraulic retention time (HRT) in the Tubificidae reactor was $15.4 \mathrm{~h}$. Dissolved oxygen (DO) in the Tubificidae reactor was maintained at 0.5-3.0 $\mathrm{mg} / \mathrm{L}$ and the temperature was maintained at above $20^{\circ} \mathrm{C}$.

In the IODVC, the average wastewater flow rate and the HRT were 7.2-8.4 $\mathrm{m}^{3} / \mathrm{d}$ and $13.2-15.4 \mathrm{~h}$ (including 1.2$1.4 \mathrm{~h}$ in the clarifier), respectively. DO in the IODVC was maintained at $1.0-2.5 \mathrm{mg} / \mathrm{L}$.
The raw wastewater was from a municipal sewer system and entered the IODVC after passing through a grit chamber. During the operation period, the average concentrations of COD, $\mathrm{NH}_{4}{ }^{+}-\mathrm{N}$, and SS were $170.0 \pm 55.6 \mathrm{mg} / \mathrm{L}$, $36.2 \pm 8.1 \mathrm{mg} / \mathrm{L}$, and $106.9 \pm 54.0 \mathrm{mg} / \mathrm{L}$, respectively. The $\mathrm{pH}$ value was changed from 7.23 to 7.40 .

In the Tubificidae reactor, the sludge was mixed and aerated using an air blower. Thus, the sludge was reduced by both Tubificidae predation and endogenous metabolism at the same time. A batch contrast experiment was carried out without Tubificidae to investigate the contribution of sludge endogenous metabolism. Sludge from the IODVC was used in batch experiment in which DO, the sludge retention time, and temperature were similar to those sludge in the Tubificidae reactor. The efficiency of endogenous metabolism was measured by the sludge decrement.

\subsection{Analytic methods}

Wastewater flow, sludge flow, DO, and temperature in the integrated system were regularly measured throughout the operation period. $\mathrm{SS}, \mathrm{NH}_{4}{ }^{+}-\mathrm{N}$ and $\mathrm{NO}_{3}{ }^{-}-\mathrm{N}$ in both influent and effluent, and MLSS and MLVSS were analyzed weekly according to standard methods (APHA, 1998; CEPB, 2004). COD and SCOD were measured with a CTL-12 COD meter (Huatong Company, China). SCOD was filtered with a $0.45-\mu \mathrm{m}$ membrane filter. The DO concentration was measured using a YSI Model 52 dissolved oxygen meter (YSI Incorporated Company, USA). The wet weight of Tubificidae was measured using an AR2140 balance (Ohaus Co., Florham, USA) after the sludge in the Tubificidae was washed off and the water was sipped up by filter paper. The floc size was measured using a Mastersizer 2000 laser particle size analyzer (Malvern Co., United Kingdom). The viscosity was measured using an NDJ-1 revolving viscosity meter (Shanghai, China). The specific resistance was determined according to the method described by Christensen and Dick (1985).

Size exclusion chromatography (SEC) was used as the analytical technique to determine the molecular weight of effluent. SEC was conducted by a HPLC (Hitachi, Japan), which consists of a diode array detector L-2450, a column oven L-2300, and a pump L-2130. The column was TSKGEL G3000PWXL $(7.8 \mathrm{~mm} \times 30.0 \mathrm{~cm})$ (Tosoh Corp.). The eluent was $0.004 \mathrm{~mol} / \mathrm{L}$ phosphate buffer solution- 0.025 $\mathrm{mol} / \mathrm{L} \mathrm{Na}_{2} \mathrm{SO}_{4}$ sodium sulfate, with $\mathrm{pH}$ 6.8.

The sludge was examined using a scanning electron microscope (SEM) (FEI QUANTA 200). The samples were fixed overnight in $2.5 \%$ glutaraldehyde, washed three times in phosphate buffer solution, and were then fixed $2-4 \mathrm{~h}$ in $1 \%$ osmic acid and were again washed three times in phosphate buffer solution. The samples were dehydrated stepwise in a graded series of water/ethanol solutions $(30 \%, 50 \%, 70 \%, 85 \%, 95 \%, 100 \%)$, and then replaced overnight in isoamyl acetate. The samples were dried by critical-point carbon dioxide (CPD030 Criti cal point Dryer) and were sputter coated with $\mathrm{Au} / \mathrm{Pt}$ (SCD005 Sputter Coater) prior to SEM observation.

The sludge reduction was measured by the sludge reduc- 
tion rate in the first stage as shown below:

$A=\left(X_{\text {in }}-X_{\text {out }}\right) \times 100 / X_{\text {in }}$

where, $A$ is the sludge reduction rate of the Tubificidae reactor $(\%) ; X_{\text {in }}$ and $X_{\text {out }}$ are the sludge concentrations of the inlet and the outlet of the Tubificidae reactor $(\mathrm{g} / \mathrm{L})$, respectively.

The sludge reduction was measured by the sludge yield in the second stage. The sludge yield in a given time was calculated as shown below (Wei, 2003a):

$$
\begin{aligned}
& \Delta \mathrm{TSS}= \mathrm{TSS}_{n+i}-\mathrm{TSS}_{n}+\mathrm{TSS}_{\mathrm{w}} \\
&=10^{-3}\left(\left(V_{\mathrm{a}} X_{\mathrm{a}}+V_{\mathrm{s}} X_{\mathrm{a}}\right)_{n+i}-\left(V_{\mathrm{a}} X_{\mathrm{a}}+V_{\mathrm{s}} X_{\mathrm{r}}\right)_{n}+i Q_{\mathrm{w}} X_{\mathrm{r}}\right) \\
& \Delta \mathrm{COD}_{\mathrm{r}}=\left(\mathrm{COD}_{\mathrm{r}}\right)_{n+i}-\left(\mathrm{COD}_{\mathrm{r}}\right)_{n}=24 \times 10^{-6} \times \\
& i \times \sum_{n}^{n+i} Q_{\mathrm{in}} \times\left(\sum_{n}^{n+i} \mathrm{COD}_{\text {in }}-\sum_{n}^{n+i} \mathrm{COD}_{\text {out }}\right)
\end{aligned}
$$

$Y=\Delta \mathrm{TSS} / \Delta \mathrm{COD}_{\mathrm{r}}$

where, $Y$ is the sludge yield during $i$ days $(\mathrm{kg} \mathrm{SS} / \mathrm{kg}$ $\mathrm{COD}_{\text {removed }}$ ); TSS is the amount of sludge produced during $i$ days (kg SS); $\mathrm{COD}_{\text {removed }}$ is the amount of COD removed during $i$ days (kg $\mathrm{COD}_{\text {removed }}$ ); $\mathrm{TSS}_{n}, \mathrm{TSS}_{n+i}$, $\mathrm{TSS}_{\mathrm{w}}$ are the amounts of sludge on days $n$ and $n+i$, and the amount of sludge wasted during $i$ days, respectively; $V_{\mathrm{a}}$ and $V_{\mathrm{s}}$ are the volumes of aeration and separation tanks (L), respectively; $X_{\mathrm{a}}$ and $X_{\mathrm{r}}$ are the total suspended solids (TSS) concentrations in the aeration tank and the returned sludge $(\mathrm{g} / \mathrm{L})$, respectively; $\mathrm{COD}_{\text {in }}$ and $\mathrm{COD}_{\text {out }}$ are the COD concentrations of influent and effluent $(\mathrm{mg} / \mathrm{L})$, respectively; $Q_{\mathrm{in}}$ is the influent flow $(\mathrm{L} / \mathrm{h}) ; Q_{\mathrm{w}}$ is the flow of the wasted sludge $(\mathrm{L} / \mathrm{d})$.

\section{Results and discussion}

\subsection{Tubificidae growth in the Tubificidae reactor}

Tubificidae were inoculated in the Tubificidae reactor in the start-up stage. The inoculated Tubificidae were a mixture of Branchnria Sowerbyi and Limnodrilns sp., but Limnodrilns sp. was dominant. The width and length of these Tubificidae were $0.1-0.4 \mathrm{~mm}$ and $3-20 \mathrm{~mm}$, respectively. The wet weight of Tubificidae were detected only on days 65,165 , and 228 because of the difficulty in taking samples during the working situation of the Tubificidae reactor. The results of microscopic investigation showed that the dominant worm of Tubificidae were transferred to Branchnria Sowerbyi on day 228 from Limnodrilns sp. in the inoculation. Almost $65 \%$ wet weight of Tubificidae turned mature in the Tubificidae reactor. The width and length of these Tubificidae were $0.7-1.2 \mathrm{~mm}$ and 35$60 \mathrm{~mm}$, respectively. The width and length of $25 \%$ of the wet weight Tubificidae were $0.4-0.5 \mathrm{~mm}$ and $30-35$ $\mathrm{mm}$, respectively. The width and length of $10 \%$ of the wet weight Tubificidae were $0.1-0.4 \mathrm{~mm}$ and $3-20 \mathrm{~mm}$, respectively. The wet weights of Tubificidae on days 65 , 165, and 228 were approximately 676.5, 379.5, and 663.3 $\mathrm{g}$, respectively. The decreased wet weight of Tubificidae on day 165 may be caused by the high temperature (above $30^{\circ} \mathrm{C}$ ) in summer. Therefore, the balance weight of Tubificidae in the vessels of this reactor was about $670 \mathrm{~g}$. The wet volume density and the area density of wet weight Tubificidae in these vessels working area were $17600 \mathrm{~g} / \mathrm{m}^{3}$ and $2417 \mathrm{~g} / \mathrm{m}^{2}$, respectively.

\subsection{Sludge reduction}

The sludge reduction in the first stage and the second stage were measured by the sludge reduction rate and the sludge yield, respectively. The results are shown in Fig.2.

In the first stage, the excess sludge was treated by the Tubificidae reactor, and the sludge concentration was reduced from $4.34 \pm 1.31 \mathrm{~g} / \mathrm{L}$ in the inlet to $2.32 \pm 0.96 \mathrm{~g} / \mathrm{L}$ in the outlet (Fig.2). The average reduced sludge was 280 g sludge/d. According to the mentioned Equation (1), the average sludge reduction rate in this stage was $46.4 \%$.

In the second stage (from day 102 to day 235), the treated sludge was returned to the IODVC. The sludge concentration in the IODVC was decreased from $3.92 \pm 1.79$ $\mathrm{g} / \mathrm{L}$ to $3.54 \pm 1.61 \mathrm{~g} / \mathrm{L}$ (Fig.2). The relationship of sludge concentration and the total COD removal in IODVC is shown in Fig.3. According to the mentioned Equations (2)-(4), the average sludge yield was $6.19 \times 10^{-5} \mathrm{~kg} \mathrm{SS} / \mathrm{kg}$ $\mathrm{COD}_{\text {removed }}$ in the second stage. The average volatile sludge yield was $3.47 \times 10^{-5} \mathrm{~kg} \mathrm{VSS} / \mathrm{kg} \mathrm{COD}_{\text {removed }}$. This value is considerably lower than the recommended values for municipal wastewater treatment by oxidation ditch, in which the sludge yield is $0.35-0.45 \mathrm{~kg} \mathrm{VSS} / \mathrm{kg}$ COD (Mandt and Bell, 1982).

In the Tubificidae reactor, the sludge reduced by Tubificidae predation and endogenous metabolism at the same time. The batch experimental results showed that the contribution of sludge reduction by endogenous metabolism

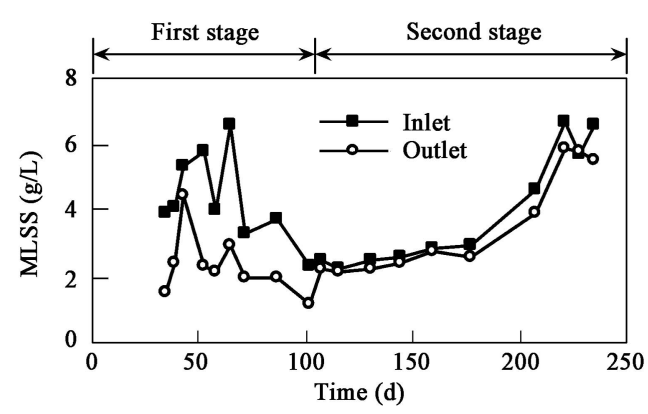

Fig. 2 Sludge reduction efficiency.

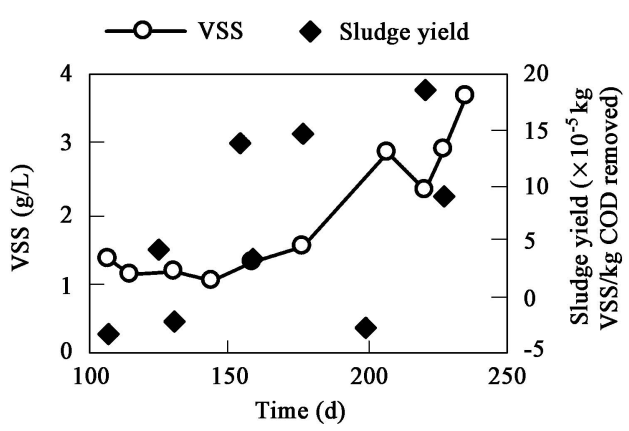

Fig. 3 VSS and sludge yield in the IODVC in the second stage. 
was less than $7 \%$ in both stages (Fig.4), though the average sludge reduction in the first stage was higher than that in the second stage.

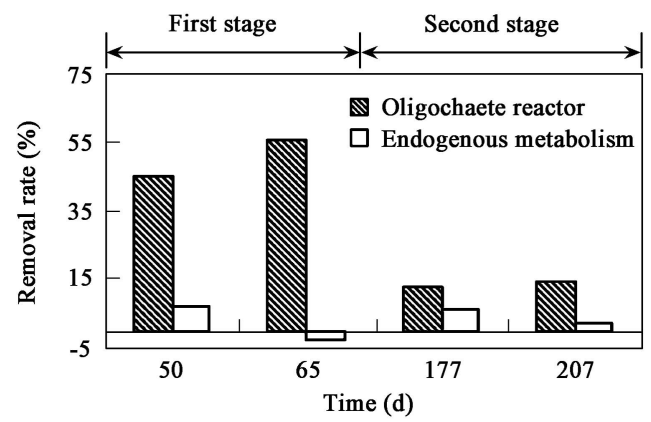

Fig. 4 Sludge reduction in the Tubificidae reactor and only treated by endogenous metabolism by a batch experiment.

\subsection{Impacts on effluent quality}

\subsubsection{Impacts on the effluent quality of the Tubificidae reactor}

It has been reported that the soluble substances $\left(\mathrm{PO}_{4}{ }^{3-}-\mathrm{P}\right.$ and total inorganic nitrogen) increased after the sludge reduced by the Tubificidae (Wei and Liu, 2005). The changes of soluble $\mathrm{COD}, \mathrm{BOD}_{5}, \mathrm{TN}$, and $\mathrm{TP}$ in the Tubificidae reactor during the continuous operation time are shown in Table 1. For further comparing the impact of Tubificidae predation on the effluent quality, the changes of soluble $\mathrm{COD}, \mathrm{BOD}_{5}, \mathrm{TN}$, and TP caused by endogenous metabolism during the batch experiment are also shown in Table 1. When compared with the decrease of soluble COD caused by the endogenous metabolism, the concentrations of soluble COD, TN, and TP increased, but $\mathrm{BOD}_{5}$ was stable in the effluent after being treated by the Tubificidae reactor. Therefore, these results showed that Tubificidae predation on sludge resulted in the increase of soluble COD and TP, and the increase of soluble TN was caused by both Tubificidae predation and endogenous metabolism.

\subsubsection{Impacts on the effluent quality of the IODVC}

Table 2 shows the results of the COD, $\mathrm{BOD}_{5}, \mathrm{TN}$, $\mathrm{NH}_{4}{ }^{+}-\mathrm{N}$, and $\mathrm{SS}$ treated by the IODVC throughout the operation period. The $\mathrm{COD}, \mathrm{BOD}_{5}$, and $\mathrm{SS}$ in the effluent were maintained at less than $44 \mathrm{mg} / \mathrm{L}, 13 \mathrm{mg} / \mathrm{L}$, and $19 \mathrm{mg} / \mathrm{L}$, respectively, and their average removal rates were $83.5 \%, 84.7 \%$, and $88.0 \%$, respectively. $\mathrm{The} \mathrm{NH}_{4}{ }^{+}-\mathrm{N}$ concentration in the effluent of the IODVC was below 1.0 $\mathrm{mg} / \mathrm{L}$, and was not detected for most of the operational period. The average removal rate of $\mathrm{NH}_{4}{ }^{+}-\mathrm{N}$ was $99.1 \%$. It can be indicated that the returned sludge from the Tubificidae reactor did not cause any significant negative influence on the effluent quality. Thus, it is feasible to return the sludge treated by Tubificidae to the IODVC.

To investigate whether new recalcitrant organic substances were produced during the sludge treated by the Tubificidae reactor, the molecular weight of dissolved organic substance in the supernatant of the influent and the effluent of the Tubificidae reactor was determined on day 186. The molecular weight chart of the effluent was similar to that of the influent. As shown in Fig.5, no new type of molecular weight of substance occurred in the effluent. These results imply that no new type of recalcitrant substance discharged into the environment when the sludge was treated by Tubificidae.

\subsection{Impacts on the activated sludge}

In the beginning of this study, the activated sludge was inoculated from a municipal wastewater treatment plant of Beijing and the initial sludge concentration in the IODVC was $2.65 \mathrm{~g} / \mathrm{L}$. In the first running mode, the excess sludge wasted from the IODVC was treated by the Tubificidae reactor and was then discharged. In this stage, the characteristics of sludge dewatering and settling were the main concerns. In the second running mode, the returned sludge was treated by the Tubificidae reactor and then returned to the IODVC. In this stage, more attention was paid to the characteristics of sludge in IODVC and the change in the Tubificidae reactor.

Table 1 Changes of soluble substances by Tubificidae predation and endogenous metabolism in the batch experiment

\begin{tabular}{|c|c|c|c|c|c|c|}
\hline & \multicolumn{3}{|c|}{ Tubificidae reactor } & \multicolumn{3}{|c|}{ Endogenous metabolism } \\
\hline & Inlet mean $\pm S D$ & Outlet mean $\pm S D$ & Average removal rate & Initial mean $\pm S D$ & Final mean $\pm S D$ & Average removal rate \\
\hline $\mathrm{COD}(\mathrm{mg} / \mathrm{L})$ & $31.1 \pm 13.4$ & $28.2 \pm 8.8$ & $-2.3 \%$ & $37.7 \pm 9.0$ & $27.3 \pm 1.8$ & $24.9 \%$ \\
\hline $\mathrm{BOD}_{5}(\mathrm{mg} / \mathrm{L})$ & 10.0 & 10.0 & $0 \%$ & - & - & - \\
\hline $\mathrm{TN}(\mathrm{mg} / \mathrm{L})$ & $42.0 \pm 8.5$ & $46.9 \pm 8.9$ & $-13.0 \%$ & $45.9 \pm 3.35$ & $48.7 \pm 2.73$ & $-6.6 \%$ \\
\hline $\mathrm{TP}(\mathrm{mg} / \mathrm{L})$ & $2.50 \pm 0.82$ & $2.89 \pm 0.90$ & $-18.8 \%$ & $2.96 \pm 0.81$ & $2.92 \pm 0.96$ & $1.87 \%$ \\
\hline
\end{tabular}

Removal rate $(\%)=($ Influent-Effluent $) \times 100 /$ Influent.

Table 2 Treatment performance of the IODVC in the two stages

\begin{tabular}{|c|c|c|c|c|c|c|}
\hline & \multicolumn{3}{|c|}{ First stage } & \multicolumn{3}{|c|}{ Second stage } \\
\hline & Influent mean $\pm S D$ & Effluent mean $\pm S D$ & $\begin{array}{l}\text { Average removal } \\
\text { rate }\end{array}$ & Influent mean $\pm S D$ & Effluent mean $\pm S D$ & $\begin{array}{l}\text { Average removal } \\
\text { rate }\end{array}$ \\
\hline $\mathrm{COD}(\mathrm{mg} / \mathrm{L})$ & $204.4 \pm 49.4$ & $26.2 \pm 7.3$ & $86.1 \%$ & $131.2 \pm 29.2$ & $24.36 \pm 8.0$ & $80.5 \%$ \\
\hline $\mathrm{BOD}_{5}(\mathrm{mg} / \mathrm{L})$ & 80 & 10 & $87.5 \%$ & 72 & 13 & $81.9 \%$ \\
\hline $\mathrm{NH}_{4}{ }^{+}-\mathrm{N}(\mathrm{mg} / \mathrm{L})$ & $36.5 \pm 7.7$ & $0.26 \pm 0.28$ & $99.1 \%$ & $36.0 \pm 8.8$ & $0.32 \pm 0.35$ & $99.2 \%$ \\
\hline $\mathrm{TN}(\mathrm{mg} / \mathrm{L})$ & $44.5 \pm 8.83$ & $44.28 \pm 7.69$ & $-0.51 \%$ & $43.1 \pm 10.2$ & $42.9 \pm 8.66$ & $-1.0 \%$ \\
\hline $\mathrm{SS}(\mathrm{mg} / \mathrm{L})$ & $130.0 \pm 56.4$ & $10.6 \pm 5.3$ & $92 \%$ & $68.5 \pm 13.7$ & $11.2 \pm 2.9$ & $82.1 \%$ \\
\hline
\end{tabular}

Removal rate $(\%)=($ Influent-Effluent $) \times 100 /$ Influent. 

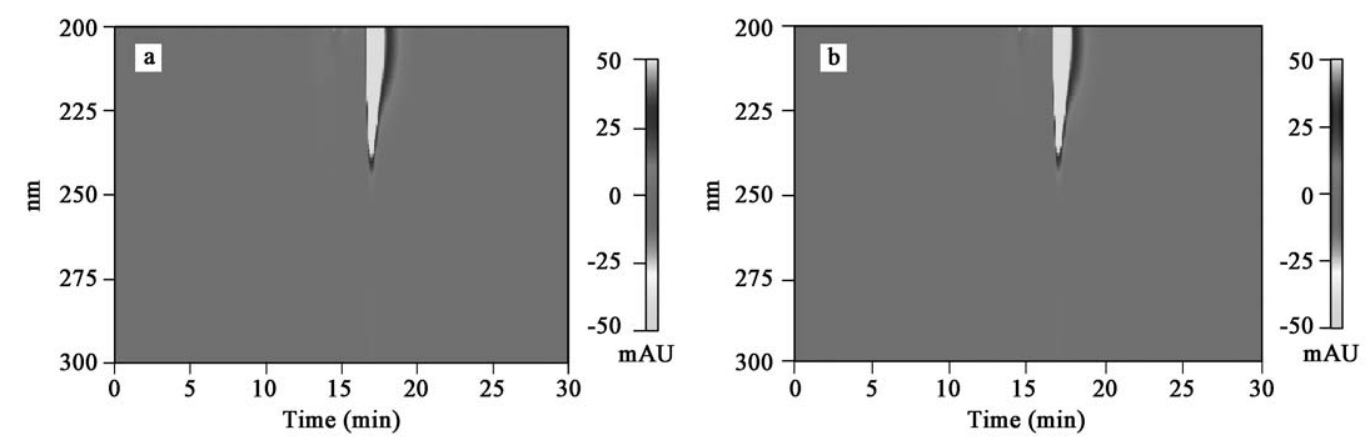

Fig. 5 Molecular weight of soluble organic substance in the supernatant of influent (a) and effluent (b) of the Tubificidae reactor.

\subsubsection{SVI and MLVSS/MLSS ratio of the sludge in the Tubificidae reactor}

In the first stage, the ratio of MLVSS/MLSS in the outlet sludge was slightly lower than that in the inlet sludge in the Tubificidae reactor, and the average difference value was 0.016 (Fig.6a). However, the SVI of the outlet sludge was higher than that in the inlet sludge in the Tubificidae reactor, and its average value of increase was $6.59 \mathrm{ml} / \mathrm{g}$. The SVI in the outlet sludge of the Tubificidae reactor varied from $35.7 \mathrm{ml} / \mathrm{g}$ to $68.6 \mathrm{ml} / \mathrm{g}$, and the average SVI was $51.2 \mathrm{ml} / \mathrm{g}$ (Fig.6b). These results indicated a good sludge settling of the discharged excess sludge after being treated by Tubificidae.

In the second stage, the SVI and the ratio of MLVSS/MLSS in the outlet sludge were lower than that in the inlet sludge in the Tubificidae reactor (Figs.6a and 6b). The SVI and the MLVSS/MLSS ratio changed indistinctly after being treated by Tubificidae.

\subsubsection{SVI and MLVSS/MLSS ratio of the sludge in the IODVC}

The SVI in the IODVC decreased after the sludge was inoculated, and was then stable after $50 \mathrm{~d}$ (Fig.6a and $6 b)$. It was reported that the worm growth contributed to the improvement of the sludge settling characteristics (Wei et al., 2003a; Wei and Liu, 2005). The value of SVI and the ratio of MLVSS/MLSS in the IODVC between $50-235 \mathrm{~d}$ varied from $37.2-53.6 \mathrm{ml} / \mathrm{g}$ and $0.33-0.63$, respectively, and their average values were $43.85 \mathrm{ml} / \mathrm{g}$ and 0.56 , respectively. These results indicated that the running mode of the Tubificidae reactor had little impact on the SVI and the ratio of MLVSS/MLSS in the IODVC. However, the running mode may contribute in maintaining the stable station of SVI and the ratio of MLVSS/MLSS in IODVC. These results also indicated that the low values of SVI and the ratio of MLVSS/MLSS had no significant negative influence on the effluent (Table 2).

\subsubsection{Viscosity and specific resistance}

Fig.7a shows the sludge viscosity of the inlet, the outlet, and the IODVC on days 58 and 193. The test temperatures on days 58 and 193 were $22^{\circ} \mathrm{C}$ and $19^{\circ} \mathrm{C}$, respectively. The viscosity of the inlet and the outlet sludge in the Tubificidae reactor was not changed after being treated
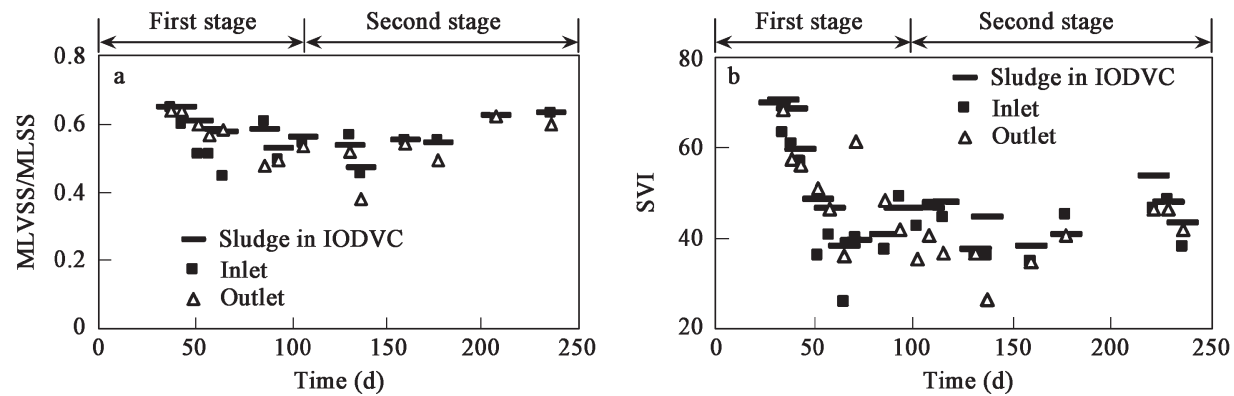

Fig. 6 Ratio of MLVSS/MLSS (a) and SVI (b) in the integrated system.
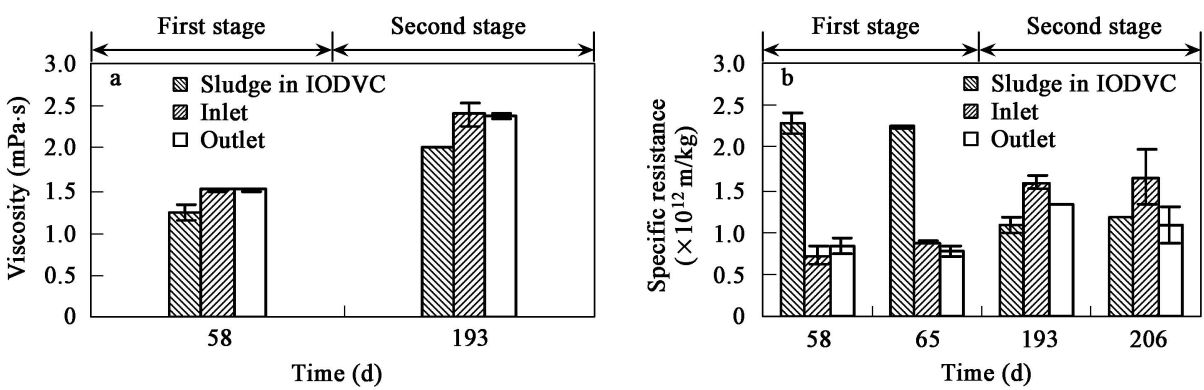

Fig. 7 Viscosity (a) and the specific resistance (b) of the sludge. 
by Tubificidae throughout the experimental period. The sludge viscosity in the IODVC in the second stage was higher than that in the first stage, and this phenomenon may be partly caused by the lower temperature in the second stage.

The specific resistance is an important factor for sludge dewatering. The specific resistance of the sludge in the Tubificidae reactor was determined on days 58 and 65 in the first stage and on days 193 and 206 in the second stage, respectively (Fig. $7 \mathrm{~b}$ ). In the first stage, the change rates of the specific resistance between the inlet and the outlet sludge on days 58 and 65 were $-16.5 \%$ and $12.1 \%$, respectively. In the second stage, the specific resistance was decreased after being treated by Tubificidae, and the decrease rate on days 193 and 206 was $16.0 \%$ and $34.7 \%$, respectively.

The specific resistance of the activated sludge in the IODVC was decreased from $(2.27 \pm 0.02) \times 10^{12} \mathrm{~m} / \mathrm{kg}$ in the first stage to $(1.13 \pm 0.05) \times 10^{12} \mathrm{~m} / \mathrm{kg}$ in the second stage. This result may be mainly caused by the decrease of specific resistance of the sludge in the Tubificidae reactor in the second stage.

\subsubsection{SEM images of the sludge}

The SEM images of the influent sludge and the effluent sludge in the Tubificidae reactor, as well as that of the sludge in IODVC when only treated by the endogenous metabolism on the day 207 are shown in Fig.8. The results of the SEM image of the sludge in the first stage on the day 92 were similar to the results on the day 207. The diversity, quantity, and activity of the bacteria were poor on the surface of these sludges because of the long SRT in the IODVC, but these characteristics in the outlet sludge were enhanced after being treated by the Tubificidae reactor. A large amount of spirillum and bacilli were detected in the outlet sludge. Thus, the characteristics of bacteria in the outlet sludge were better than that of the rest. This may be caused by the preying sludge of Tubificidae, because the characteristics of the sludge only treated by the
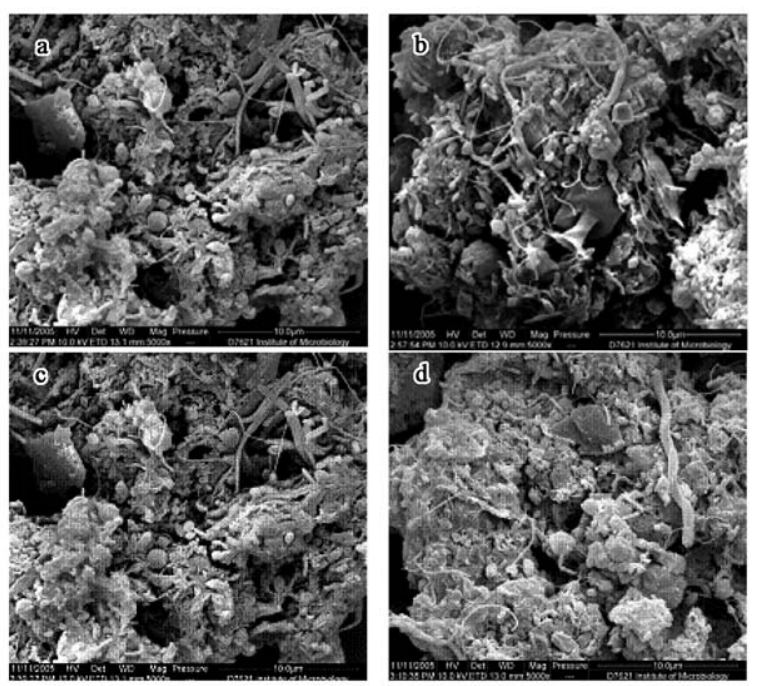

Fig. 8 SEM images of the (a) inlet, (b) outlet in the Tubificidae reactor, (c) sludge in the IODVC and (d) sludge only treated by the endogenous metabolism on day 207. endogenous metabolism were considerably worse than the rest.

\subsubsection{Floc size distribution of the sludge}

Fig.9 shows the floc size distribution of the influent sludge and the effluent sludge in the Tubificidae reactor and the sludge in the IODVC on day 207. The chart of the floc size distribution on day 59 in the first stage was similar to that on day 207 in the second stage. The $d(0.5)$ values of the influent sludge and the effluent sludge in the Tubificidae reactor on days 59 and 207 were $97.496 \mu \mathrm{m}$ and $92.31 \mu \mathrm{m}$, and $123.8 \mu \mathrm{m}$ and $127.5 \mu \mathrm{m}$, respectively, and that of the sludge in the IODVC on days 59 and 207 were $91.835 \mu \mathrm{m}$ and $117.6 \mu \mathrm{m}$, respectively.

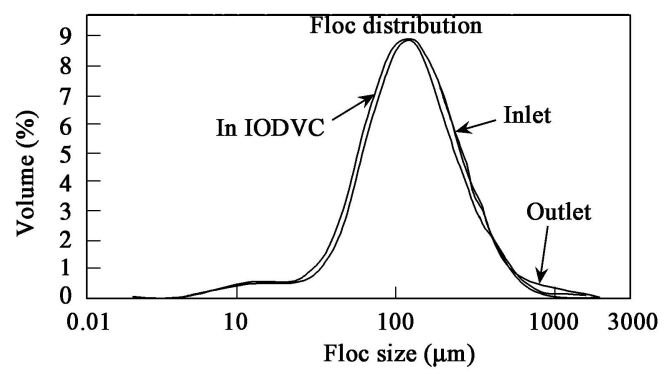

Fig. 9 Profiles of the floc size of the sludge in the second stage on day 207.

It can be indicated (Figs.6-9) that the sludge was slightly changed after being treated by the Tubificidae reactor. After being treated by the Tubificidae, no significant negative impact occurred on the sludge, and some characteristics of the sludge turned out to be better. The sludge in the IODVC was not only impacted by the Tubificidae reactor, but was also impacted by the operation condition of IODVC.

\section{Conclusions}

The Tubificidae grew and the dominating category was Branchnria Sowerbyi in the Tubificidae reactor. When the Tubificidae reactor treated the excess sludge of the IODVC, the sludge reduction rate of the excess sludge was $46.4 \%$. When the Tubificidae reactor treated the returned sludge of the IODVC, the average sludge yield of this integrated system was $6.19 \times 10^{-5} \mathrm{~kg} \mathrm{SS} / \mathrm{kg}$ COD. No new type of recalcitrant substance in the supernatant was discharged into the environment when the sludge was treated by Tubificidae. In the second stage, the returned sludge from the Tubificidae reactor did not cause any significant negative influence on the effluent quality.

No significant difference occurred on the viscosity, specific resistance, and the floc size distribution when the sludge was treated by Tubificidae. The diversity, quantity, and activeness of the bacteria in the outlet were enhanced after being treated by the Tubificidae reactor. Thus, it was feasible to return the treated sludge from the Tubificidae reactor to the IODVC. Sometimes, the discharging of some sludge may enhance the SVI and MLVSS/MLSS. The sludge in the IODVC was also impacted by the operation 
condition of IODVC.

\section{References}

APHA (American Public Health Association/American Water Works Association/Water Environment Federation), 1998. Standard methods for the examination of water and wastewater[S]. 20th ed. Washington DC, USA.

CEPB (China Environmental Protection Bureau), 2004. Standard methods forexamination of water and wastewater (2002)[M]. 4th ed. Beijing: Chinese Environmental Science Press.

Christensen G L, Dick R I, 1985. Specific resistance measurements: methods and measurements[J]. J Environ Eng ASCE, 111(3): 258-271.

Eikelboom D H, 2000. Process control of activated sludge plants by microscopic investigation[M]. UK: IWA Publishing. 85102.

Ghyoot W, Verstraete W, 2000. Reduced sludge production in a two-stage membrane-assisted bioreactor[J]. Wat Res, 34(1): 205-215.

Janssen P M J, Rulkens W H, Rensink J H et al., 1998. The potential for metazoa in biological wastewater treatment[C]. Water Quality International (WQI), Sep/Oct: 25-27.

Lee N M, Welander T, 1994. Influence of predator in nitrification in aerobic biofilm[J]. Wat Sci and Tech, 29(7): 355-363.

Lee N M, Welander T, 1996a. Reducing sludge production in aerobic wastewater treatment through manipulation of the ecosystem[J]. Wat Res, 30(8): 1781-1790.

Lee N M, Welander T, 1996b. Use of protozoa and metazoa for decreasing sludge production in aerobic wastewater treatment[J]. Biotechnology Letters, 18(4): 429-434.

Lapinski J, Tunnacliffe A, 2003. Reduction of suspended biomass in municipal wastewater using bdelloid rotifers $[\mathrm{J}]$. Wat Res, 37(9): 2027-2034.

Mandt M G, Bell B A, 1982. Oxidation ditches in wasterwater treatment[M]. Ann Arbor, Michigan, USA: Ann Arbor Science Publishers.
Ratsak C H, Kooijman S A L M, Kooi B W, 1993. Modelling the growth of an oligochaete on activated sludge[J]. Wat Res, 27(5): 739-747.

Ratsak C H, 1994. Grazer induced sludge reduction in wastewater treatment[D]. Ph.D thesis. Vrije University, the Netherlands.

Ratsak C H, 2001. Effects of Nais elinguis on the performance of an activated sludge plant[J]. Hydrobiologia, 463: 217-222.

Rensink J H, Corstanje R, van der Pal J H, 1996. A new approach to sludge reduction by metazoa[C]. In 10th European Sewage and Reuse Symposium, IFAT 1996, Munchen. 339364.

Rensink J H, Rulkens W H, 1997. Using metazoa to reduce sludge production[J]. Wat Sci and Tech, 36(11): 171-179.

Wei Y, van Houten R T, Borger A R et al., 2003a. Comparison performances of membrane bioreactor and conventional activated sludge processes on sludge reduction induced by Oligochaete[J]. Environ Sci Technol, 37: 3171-3180.

Wei Y S, van Houten R T, Borger A R et al, 2003b. Minimization of excess sludge production for biological wastewater treatment[J]. Wat Res, 37: 4453-4467.

Welander T, Lee N M, 1994. Minimization of sludge production in aerobic treatment by use of predators[C]. The Second International Symposium on Environmental Biotechnology, 4-6 July 1994, Brighton, UK.

Wei Y S, Guo X S, Liu J X, 2004. Minimization of sludge production in activated sludge process with oligochaeta[C]. The 12th International Symposium on River and Lake Environment. November 1-4, Wuhan, China.

Wei Y S, Liu J X, 2005. The discharged excess sludge treated by oligochaete[J]. Wat Sci and Tech, 52(10/11): 265-272.

Xia S, Liu J, 2004. An innovative integrated oxidation ditch with vertical circle for domestic wastewater treatment[J]. Process Biochemistry, 39: 1111-1117.

Zhang S Y, 2000. Polluted water treatment by the combining processes of membrane separation and biodegradation[D]. Ph.D thesis. Research Centre for Eco-Environmental Sciences, Chinese Academy of Sciences, China. 